\title{
The association between sleep duration and stroke differs by race and sex
}

Matthew P. Pase, PhD

Neurology ${ }^{\circledR}$ 2018;91:e1728-e1731. doi:10.1212/WNL.0000000000006420

\section{What did the authors study?}

The risk of stroke has been decreasing in older adults. ${ }^{1}$ However, stroke is still the second leading cause of death worldwide. ${ }^{2}$ In the United States, there are also major racial and geographic differences, with stroke unequally affecting African Americans and residents of the southeastern United States. ${ }^{3}$ For this reason, it is important to identify new risk and protective factors for stroke, particularly in those where stroke is most common. The article by Petrov and coauthors ${ }^{4}$ titled "Sleep duration and risk of incident stroke by age, sex, and race: the REGARDS study" examines the association between sleep duration and risk of stroke. It also explores whether findings are different between black and white adults, men and women, and younger ( $<65$ years) and older ( $\geq 65$ years) adults.

\section{How was the study done?}

The researchers asked 16,733 black and white participants aged more than or equal to 45 years to indicate their typical sleep duration. The researchers calculated the average sleep duration across both weekdays and weekends for each participant and then followed participants for an average of 6 years to see who developed stroke. During follow-up, the occurrence of stroke was determined by contact with the study participants every 6 months as well as review of medical records by a study physician. By comparing to persons with normal sleep duration (7-8.9 hours per night), the researchers investigated whether participants with either short (less than 6 hours) or long (more than 9 hours) sleep duration displayed a higher risk of developing stroke. The researchers examined if results differed according to race (black vs white), sex (men vs women), or age (under 65 years vs 65 years and older).

\section{What did the study show?}

About $10 \%$ of all participants were short sleepers, of which black participants accounted for $60 \%$. About $7 \%$ of all participants were long sleepers, of which black participants accounted for $30 \%$. During follow-up, the researchers observed 460 cases of stroke. Short sleep duration was associated with a lower risk of stroke in black participants and a higher risk of stroke in white participants. After considering other stroke risk factors such as smoking and heart disease, the lower risk of stroke in black participants who were short sleepers remained, whereas the increased risk in white participants who were short sleepers was no longer evident. The researchers then examined the effects of sex and race combined. Results revealed that short sleep duration was associated with a decreased risk of stroke in black men and long sleep duration was associated with an increased risk of stroke in white men. Findings did not differ according to age (older vs younger than age 65 years).

\section{What does the study mean?}

Other investigators have found both short and long sleep duration to be associated with an increased risk of stroke, although race and sex differences have not been well studied. The study by Petrov and coauthors reports that short sleep duration was associated with a decreased risk of stroke 
in black participants, particularly black men, whereas long sleep duration was associated with an increased risk of stroke in white men. The reduced risk of stroke observed among short sleepers who were black, particularly black men, was not expected. The results indicate that the relationship between sleep duration and stroke risk depends on race and sex. However, the reasons for this are unclear. In this study, the researchers relied on participants to self-report their sleep duration. Therefore, it is unclear if the differing results observed between race and sex groups are due to differences in sleep biology or differences in the way the groups perceived their sleep. The results could also be due to unmeasured factors such as social pressures or life stressors. These factors could vary by race or sex and therefore have different effects on sleep time and stroke risk. In the future, researchers could perform overnight monitoring of sleep to determine sleep duration more accurately and to understand what contributes to long or short sleep duration.
Most medical research is conducted without regard for race or sex differences. The study highlights how a blanket "one size fits all" approach misses the complexities that exist between different groups of people. To make research relevant to all people, researchers should consider exploring for and reporting differences by sex and race when investigating stroke risk factors.

\section{References}

1. Koton S, Schneider ALC, Rosamond WD, et al. Stroke incidence and mortality trends in US communities, 1987 to 2011. JAMA 2014;312:259-268.

2. World Health Organization.Global Health Estimates 2016: Deaths by Cause, Age, Sex, by Country and by Region, 2000-2016. Geneva: World Health Organization; 2018.

3. Benjamin EJ, Blaha MJ, Chiuve SE, et al; American Heart Association Statistics Committee and Stroke Statistics Subcommittee. Heart disease and stroke statistics: 2017 update: a report from the American Heart Association. Circulation 2017;135: e146-e603.

4. Petrov ME, Howard G, Grandner MA, et al. Sleep duration and risk of incident stroke by age, sex, and race: the REGARDS study. Neurology 2018;91: e1702-e1709. 


\section{About stroke}

Matthew P. Pase, PhD

Neurology ${ }^{\circledR}$ 2018;91:e1728-e1731. doi:10.1212/WNL.0000000000006420

Adapted from Jones SH, Karceski SC. Body mass index in early life and stroke in adult life: what is a stroke? Neurology 2017;89:e41-e44.

\section{What is stroke?}

There are 2 kinds of stroke. In the first type, called ischemic stroke, there is loss of blood flow to a certain part of the brain. About $85 \%$ of all strokes are ischemic. Often this is caused by a blockage in a blood vessel. When blocked, blood and oxygen cannot get to the area of brain that the blood vessel supplies. If this goes on long enough, the brain cells begin to die. Ischemic stroke can be caused by narrowing of the large arteries to the brain, also known as atherosclerosis. In other people, a clot can form in arteries of the neck. If a piece of the clot breaks off, it can travel to the brain and block a brain blood vessel. In the same way, clots may also form in the heart, and travel by blood flow to the brain vessels, causing stroke.

In the second type of stroke, bleeding occurs into the brain: this is called a hemorrhagic stroke. Bleeding may occur for several reasons. In one type, an aneurysm, which is a weakened blood vessel, breaks open or ruptures. When this happens, the bleeding put$s$ pressure on surrounding brain. The pressure injures and possibly kills the nearby brain cells.

In either type of stroke, the resulting brain damage may cause weakness, numbness, and speech problems. If the stroke is severe enough, it can lead to coma, and possibly death. Fortunately, there are effective ways to prevent stroke. If you have a stroke, seeking immediate medical attention can help reduce your chances of death and disability.

\section{Who gets stroke?}

Stroke is the second leading cause of death worldwide. Every year, about 800,000 people in the United States have a stroke. Although strokes occur in young and middle-aged adults, the chances of having a stroke increase in older age. As compared to men, women have a higher risk of developing stroke over the course of their lifetime; however, men have a higher risk of stroke in young adulthood and midlife. In the United States, African Americans are at greatest risk for stroke compared to other races.

\section{Treatment of stroke}

There are many treatments for strokes. Treatment selection depends on whether the stroke is ischemic or hemorrhagic. A picture of the brain, such as a CT or MRI scan, is usually performed to determine the type of stroke. Once a doctor determines whether the stroke is ischemic or hemorrhagic, treatment can begin.

Ischemic stroke, if identified early, can be treated with tissue plasminogen activator (tPA), a medication that breaks down the clot blocking the blood vessel in the brain. IPA is only effective if given within hours of stroke onset. This is one reason why the time of onset of the stroke is so important to remember.

Treatment of hemorrhagic stroke is very different from that of ischemic stroke. The treatment of hemorrhagic stroke depends on the cause of the bleeding and how much bleeding has occurred. Some hemorrhagic strokes require treatment by a surgeon. 
Prevention is the key

There are many risk factors for stroke. Some risk factors for stroke cannot be prevented. We cannot change our age, race, or family history of stroke. However, we can work on things like high blood pressure, an irregular heart rate (like atrial fibrillation), diabetes, cigarette smoking, high cholesterol (and fat levels in the bloodstream), alcohol abuse, and obesity. Treatment is available for all of these risk factors, and appropriate treatment can substantially reduce risk of stroke.

\section{For more information}

Brain \& Life

brainandlife.org

National Stroke Association

stroke.org

American Stroke Association heart.org/ 


\section{Neurology}

\section{The association between sleep duration and stroke differs by race and sex Matthew P. Pase \\ Neurology 2018;91; e1728-e1731 \\ DOI 10.1212/WNL.0000000000006420}

This information is current as of October 29, 2018

\section{Updated Information \& Services}

References

Subspecialty Collections

Permissions \& Licensing

Reprints including high resolution figures, can be found at: http://n.neurology.org/content/91/18/e1728.full

This article cites 3 articles, 2 of which you can access for free at: http://n.neurology.org/content/91/18/e1728.full\#ref-list-1

This article, along with others on similar topics, appears in the following collection(s):

All Cerebrovascular disease/Stroke

http://n.neurology.org/cgi/collection/all_cerebrovascular_disease_strok

Other cerebrovascular disease/ Stroke

http://n.neurology.org/cgi/collection/other_cerebrovascular_disease_s troke

Stroke prevention

http://n.neurology.org/cgi/collection/stroke_prevention

Information about reproducing this article in parts (figures,tables) or in its entirety can be found online at:

http://www.neurology.org/about/about_the_journal\#permissions

Information about ordering reprints can be found online: http://n.neurology.org/subscribers/advertise

Neurology ${ }^{\circledR}$ is the official journal of the American Academy of Neurology. Published continuously since 1951 , it is now a weekly with 48 issues per year. Copyright @ 2018 American Academy of Neurology. All rights reserved. Print ISSN: 0028-3878. Online ISSN: 1526-632X.

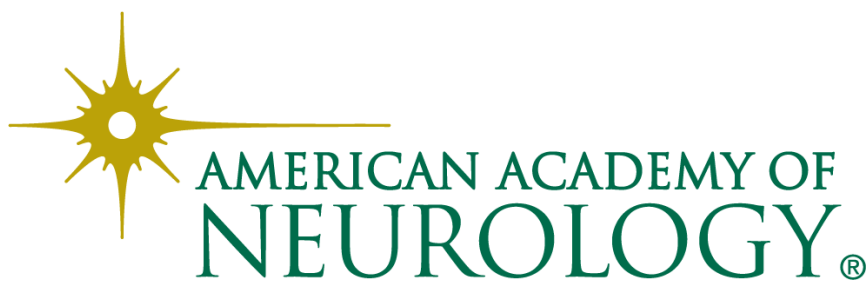

